\title{
Assessment of Barriers and Motivators in E-teaching among Medical Faculty of Punjab during COVID-19 Lockdown
}

\author{
Amandeep Singh ${ }^{1}$, Sanjeev Mahajan ${ }^{1}$, Harjot Kaur ${ }^{1 *}$, Mohan Lal' ${ }^{1}$ Gagandeep Singh ${ }^{2}$ and \\ Prabhjot Kaur ${ }^{3}$ \\ 'Department of Community Medicine, Government Medical College, Amritsar - 143001, Punjab, India; \\ adsingh.doctor@gmail.com,drsanjeevmahajan@gmail.com,drharjotkaur@gmail.com, \\ drmohanlal2014@gmail.com \\ 2Department of Pathology, Government Medical College, Amritsar - 143001, Punjab, India; \\ drgagandeep86@gmail.com \\ ${ }^{3}$ Department of Microbiology, Government Medical College, Amritsar - 143001, Punjab, India; \\ doctor.prabhjotkaur@gmail.com
}

\begin{abstract}
Background: The nationwide lockdown due to the spread of Corona virus Disease (COVID-19) has led to the disruption of several activities of everyday life including education. This had to shift towards e-learning and teaching to continue the uninterrupted flow of knowledge. Though e-teaching proves to be an effective teaching modality in current times, it's not without its limitations and challenges. It is necessary to find out the problems faced by the teachers involved in e-teaching and the motivating factors so that improvements can be made in the current teaching modality to render it more effective and productive and solve the need of the hour. Methods: This descriptive cross-sectional study was conducted among the teaching faculty of the medical institutions of Punjab. The data collection tool was a semi-structured self-made questionnaire prepared using 'Google Forms', which was then shared in the WhatsApp groups. Received responses were imported to the Microsoft Excel sheet and statistical analysis was done. Results: $97.1 \%$ of teachers were facing some kind of problem in e-teaching, most common of which were lack of personal interaction with the teachers (91.9\%), poor response from students (54.5\%), frequent technological failures/limited access to the internet (54.5\%), Lack of training regarding the use of digital platforms/unprepared for e-teaching (25.4\%), etc. Major motivating factors were the ability to share a variety of updated content with students (58.4\%), increased flexibility of location (53.6\%), being able to keep in touch with students and the subject even during the lockdown (48.8\%), development of digital expertise $(41.6 \%)$, the flexibility of time $(29.7 \%)$, etc. Discussion: Online teaching cannot be a substitute to routine classroom teaching, however, it can be used as a supplement along with the routine teaching to share more content with the students, to give assignments, to receive feedback, etc. as suggested by most of the participants in this study.
\end{abstract}

Keywords: COVID-19, Medical Education, Medical Faculty, Online Learning, Teaching Hospital

\section{Introduction}

The nationwide lockdown due to the spread of Corona Virus Disease (COVID-19) has led to the disruption of several activities of everyday life including education. However, education and knowledge dissemination should not suffer despite the lockdown. The need for continuing education has led to the adoption of digital tools and

${ }^{*}$ Author for correspondence 
techniques in this field. Schools, colleges and universities have had to shift towards e-learning and teaching to continue the uninterrupted flow of knowledge. Academic institutes gradually initiated online meetings and classes in March and started coping-up with the situation 1 .

The term e-learning is defined as "instructional content or learning experiences delivered or enabled by electronic technology" $=$. E-learning provides a gateway for the young minds to indulge in learning despite the lockdown which keeps them productive and helps them not lose connection with the subjects. E-learning has the potential to offer many advantages beyond those of more traditional forms of training and development at the level of the individual learner and at the organizational level. The use of e-learning and teaching in the workplace has become widespread and with the continuing emergence of new technologies, growth in popularity is expected to continue.

The current paradigm shift in teaching methods has placed a great responsibility on the shoulders of teachers in schools and colleges to be innovative and adapt new and interesting digital tools to make learning more interesting. A typical online course needs contents preparation and modern educational technology (Video/ audio/mixed) to connect the content with students.

Though the e-teaching proves to be an effective teaching modality in current times, it's not without its limitations and challenges. Lockdown stopped the regular classes in between a running semester (Jan-May) in most cases, which led to rethinking and re-planning of courses from offline to online. Teachers had no clarity on what tools and technologies to use $\frac{1}{}$. Lots of other problems like low and irregular attendance, lack of attention by students; the fear of technology (especially among older teachers), poor internet connectivity, and in most cases, the added pressure of household chores, have made online teaching a dreaded activity for many teachers ${ }^{3}$.

An uninterrupted flow of knowledge is even more necessary where medical education is concerned because stopping classes altogether cannot be afforded in this case. Therefore, this field is also facing the same kind of challenges with the inclusion of e-teaching as the teaching modality in most of the academic institutions. Hence, it's the need of the hour to assess the difficulties faced by the teachers in e-teaching and also various benefits of e-teaching perceived by them.

\section{Methodology}

This descriptive cross-sectional study was conducted among teaching faculty of medical institutions of Punjab including those of MBBS, BDS, BPT and B.Sc. Nursing. This study was conducted in mid-May 2020 after the approval from the Institutional Ethics Committee, approximately one month after the commencement of online classes in the medical institutions of Punjab.

\subsection{Strategy for Data Collection}

A semi-structured questionnaire was prepared via 'Google Forms'. This consisted of 26 open- and closeended questions. Google Forms link of the questionnaire was shared in the WhatsApp groups of the faculty of various Medical, Dental, Physiotherapy and Nursing Colleges of Punjab. Instructions regarding filling the questionnaire were mentioned in the description of the Google Form. The questionnaire includes the following components:

- Socio demographic data of the participants.

- Questions about general concepts of e-teaching.

- Questions assessing barriers in e-teaching.

- Questions about the benefits of e-teaching.

- Questions about training and suggestions for improvement.

The questionnaire was self-made keeping in view the aims and objectives of this study and pre-tested by conducting a pilot study on $10 \%$ of the required sample size and the changes were incorporated in the questionnaire afterward. Consent was obtained in the first section of the form stating that they were volunteering to participate in the study and confidentiality of the personal details was maintained. The two weeks were provided for submitting the responses after sharing the link. The teachers in all the colleges of Punjab under medical education and involved in e-teaching process were included in this study and the teachers not providing consent were excluded from the study.

\subsection{Sample size Calculation}

To calculate the sample size, the following formula (Daniel, 1999) was used:

$\mathrm{n}=\mathrm{Z}^{2} \mathrm{P}(1-\mathrm{P}) / \mathrm{d}^{2}$

Where $\mathrm{n}=$ sample size,

$\mathrm{Z}=\mathrm{Z}$ statistic for a level of confidence, 
$\mathrm{P}=$ expected prevalence or proportion (In proportion of one; if $50 \%, \mathrm{P}=0.5)$

$\mathrm{d}=$ precision (in proportion of one; if $5 \%, \mathrm{~d}=0.05$ ).

$\mathrm{Z}$ statistic (Z): For the level of confidence of $95 \%$, which is conventional, the $Z$ value is 1.96 .

Assuming the prevalence of barriers perceived by teachers as $50 \%$, with an allowable error of $10 \%$, the calculated sample size comes out to be 100 . However, 230 responses were received and 209 responses fulfilling inclusion criteria were analyzed.

\subsection{Data Analysis}

Data analysis was performed on Microsoft Excel. Data were expressed as mean \pm standard deviation and number (percentage). The Chi-Square test was applied to test the level of significance among categorical variables. P-value less than 0.05 was considered statistically significant.

\subsection{Ethical considerations}

This study was registered at the Government Medical
College Ethics Committee under the research project number IEC/GMC/2048. Consent was obtained in the first section of the form stating that they were volunteering to participate in the study. Participants were also assured of the data confidentiality, and all the questionnaires were kept anonymous. The study was conducted per the ethical standards of the Institutional Ethics Committee.

\section{Results}

This study included responses from 209 teachers in the analysis. The mean age of participants was 42.5 with standard deviation (SD) of 9.5. The basic profile of the faculty reveals that more responses came from females, probably due to higher proportion of females in nursing college faculty. We received most of the responses from medical colleges may be because of more faculty in medical colleges. Most faculty members had teaching experience of more than 10 years. Details are enlisted in Table 1.

Table 1. Basic profile of the faculty

\begin{tabular}{|l|l|l|l|}
\hline Particulars & & Frequency & Percentage \\
\hline \multirow{4}{*}{ Age Group (in years) } & $21-30$ & 21 & 10.0 \\
\cline { 2 - 5 } & $31-40$ & 81 & 38.8 \\
\cline { 2 - 5 } & $41-50$ & 54 & 25.8 \\
\cline { 2 - 5 } Gender & $51-60$ & 45 & 21.5 \\
\cline { 2 - 5 } & $61-70$ & 8 & 3.8 \\
\hline \multirow{5}{*}{ College } & Female & 115 & 55.0 \\
\cline { 2 - 5 } & Male & 94 & 45.0 \\
\hline & Medical College & 113 & 54.1 \\
\cline { 2 - 5 } & Nursing College & 42 & 20.1 \\
\cline { 2 - 5 } & Dental College & 28 & 13.4 \\
\cline { 2 - 5 } & Physiotherapy College & 26 & 12.4 \\
\hline
\end{tabular}




\section{Table 1 Continued}

\begin{tabular}{|l|l|l|l|}
\hline \multirow{4}{*}{ Type of institute } & Private College & 113 & 54.1 \\
\cline { 2 - 5 } & Government College & 96 & 45.9 \\
\hline \multirow{4}{*}{ Teaching Experience } & $<3$ years & 30 & 14.4 \\
\cline { 2 - 5 } & $3-5$ years & 31 & 14.8 \\
\cline { 2 - 5 } & $5-10$ years & 56 & 26.8 \\
\cline { 2 - 5 } & $>10$ years & 92 & 44.0 \\
\hline \multirow{2}{*}{ Total } & & 209 & 100.0 \\
\hline
\end{tabular}

Table 2. Details of e-teaching

\begin{tabular}{|c|c|c|c|}
\hline Aspect & & Frequency & Percentage \\
\hline \multirow{4}{*}{$\begin{array}{l}\text { Mode of e-teaching } \\
\text { (Multiple responses allowed) }\end{array}$} & Live video lectures & 110 & 52.6 \\
\hline & Recorded video lectures & 90 & 43.1 \\
\hline & $\begin{array}{l}\text { Written material in form of PPTs, } \\
\text { PDFs, etc. }\end{array}$ & 26 & 12.4 \\
\hline & PPTs along with audio recordings & 26 & 12.4 \\
\hline \multirow{5}{*}{$\begin{array}{l}\text { Frequency of e-teaching } \\
\text { (classes/videos/written notes) }\end{array}$} & 3-4 per day & 9 & 4.3 \\
\hline & $1-2$ per day & 9 & 4.3 \\
\hline & 3-4 per week & 30 & 14.4 \\
\hline & 1-2 per week & 134 & 64.1 \\
\hline & Once in 2 weeks & 27 & 12.9 \\
\hline \multirow{8}{*}{$\begin{array}{l}\text { Software/s used for e-teaching } \\
\text { (Multiple responses allowed) }\end{array}$} & Zoom Meetings & 87 & 41.6 \\
\hline & YouTube & 65 & 31.1 \\
\hline & WhatsApp & 49 & 23.4 \\
\hline & Email & 26 & 12.4 \\
\hline & Telegram & 25 & 12 \\
\hline & Google Classroom & 21 & 10 \\
\hline & Free Conference Call & 15 & 7.2 \\
\hline & Google Meet & 8 & 3.8 \\
\hline
\end{tabular}




\section{Table 2 Continued}

\begin{tabular}{|c|c|c|c|}
\hline \multirow{3}{*}{ E teaching done from } & $\begin{array}{l}\text { Digital classroom/lecture theatre of } \\
\text { the institute }\end{array}$ & 105 & 50.2 \\
\hline & Department & 61 & 29.2 \\
\hline & Home & 43 & 20.6 \\
\hline \multirow{2}{*}{$\begin{array}{l}\text { Internet connection used for } \\
\text { e-teaching }\end{array}$} & Institute's & 122 & 58.4 \\
\hline & Personal & 87 & 41.6 \\
\hline \multirow{2}{*}{ Devices used for e-teaching } & Institute's & 119 & 56.9 \\
\hline & Personal & 90 & 43.1 \\
\hline \multirow{2}{*}{$\begin{array}{l}\text { Using any online platform } \\
\text { for providing assignments/ } \\
\text { assessments? }\end{array}$} & Yes & 115 & 55.0 \\
\hline & No & 94 & 45.0 \\
\hline \multirow{5}{*}{$\begin{array}{l}\text { Software/s used for online } \\
\text { assignments } \\
\text { (Multiple responses allowed) }\end{array}$} & Google Forms/Google Classroom & 81 & 38.8 \\
\hline & WhatsApp & 18 & 8.6 \\
\hline & Class Marker & 12 & 5.7 \\
\hline & Email & 9 & 4.3 \\
\hline & Survey Monkey & 8 & 3.8 \\
\hline Total & & 209 & 100.0 \\
\hline
\end{tabular}

Table 2 states that most of the teachers (52.6\%) were teaching via live video lectures while $43.1 \%$ were sharing recorded video lectures with the students. Other modes of e-teaching were sharing written material (12.4\%) and sharing PPTs along with audio recordings (12.4\%). Mostly (64.1\%), faculty were taking 1-2 lectures per week. Most of the faculty members were using Zoom App for teaching followed by other applications like YouTube, WhatsApp, Email, Telegram, Google classroom, Free
Conference Call, Google Meet, etc. 50\% of faculty was teaching from the digital classroom of the institution, $29.2 \%$ from the department and $20.6 \%$ from home. $58.4 \%$ were using the institute's internet and $41.6 \%$ personal. $55 \%$ of faculty were sharing assignments with students via Google Forms/Google Classroom, WhatsApp, Class Marker, Email, and Survey Monkey in this order.

Table 3 represents the feedback of teachers regarding online-teaching. According to $41.6 \%$ of teachers, $70-90 \%$ 
Table 3. Feedback of the teachers

\begin{tabular}{|c|c|c|c|}
\hline Aspect & & Frequency & Percentage \\
\hline \multirow{4}{*}{$\begin{array}{l}\text { Average number of students } \\
\text { attending/reading e lectures? }\end{array}$} & $>90 \%$ & 31 & 14.8 \\
\hline & $70-90 \%$ & 87 & 41.6 \\
\hline & $50-70 \%$ & 48 & 23.0 \\
\hline & Don't Know & 43 & 20.6 \\
\hline \multirow{5}{*}{$\begin{array}{l}\text { Average number of students } \\
\text { submitting online assignments }\end{array}$} & $>90 \%$ & 27 & 12.9 \\
\hline & $70-90 \%$ & 35 & 16.7 \\
\hline & $50-70 \%$ & 46 & 22.0 \\
\hline & $<50 \%$ & 7 & 3.3 \\
\hline & Not providing assignments & 94 & 45.0 \\
\hline \multirow{2}{*}{$\begin{array}{l}\text { Previous training on the use of } \\
\text { digital platforms for e-teaching? }\end{array}$} & Yes & 35 & 16.7 \\
\hline & No & 174 & 83.3 \\
\hline \multirow{3}{*}{$\begin{array}{l}\text { Previous expertise in the use of } \\
\text { digital platforms like Microsoft } \\
\text { Office, email, etc }\end{array}$} & Yes & 89 & 42.6 \\
\hline & Somewhat & 104 & 49.8 \\
\hline & No & 16 & 7.7 \\
\hline \multirow{3}{*}{$\begin{array}{l}\text { Do you feel that e-teaching is } \\
\text { useful? }\end{array}$} & Yes & 80 & 38.3 \\
\hline & Somewhat & 100 & 47.8 \\
\hline & No & 29 & 13.9 \\
\hline \multirow{3}{*}{$\begin{array}{l}\text { Can e-teaching be incorporated } \\
\text { as a supplement to the regular } \\
\text { teaching? }\end{array}$} & Yes & 104 & 49.8 \\
\hline & No & 71 & 34.0 \\
\hline & Can't say & 34 & 16.3 \\
\hline Total & & 209 & 100.0 \\
\hline
\end{tabular}


of students were attending or reading the online lectures. Online assignments were submitted by $50-70 \%$ of students in $22 \%$ cases, $70-90 \%$ in $16.7 \%$ cases, more than $90 \%$ of students submitted assignments in $12.9 \%$ cases while less than $50 \%$ submitted in $3.3 \%$ cases. $83.3 \%$ had not received any kind of training on the use of digital platforms while $49.8 \%$ were somewhat expert and $42.6 \%$ felt they were experts in using digital platforms like Microsoft Office, email, etc. Regarding the usefulness of online-teaching, $47.8 \%$ were of the view that it was somewhat useful while $38.3 \%$ felt it was useful in the current situation. $49.8 \%$ thought that online-teaching can be incorporated in the routine-teaching curriculum as an aid to face to face teaching.

Table 4 states that the major problem faced by the teachers in e-teaching was lack of personal interaction with the teachers (91.9\%) followed by poor response from students (54.5\%), frequent technological failures/limited access to the internet (54.5\%), Lack of training regarding the use of digital platforms/unprepared for e-teaching (25.4\%), difficulty in creating lesson plans $(25.4 \%)$, lack of adequate devices/hardware (21.1\%), visual fatigue (19.1\%), increased workload (17.7\%), personal fear of e-teaching $(9.6 \%)$, distractions during teaching $(4.3 \%)$ and none in $2.9 \%$ cases.

Table 4. Problems/difficulties faced during the e-teaching process. (Multiple responses were allowed)

\begin{tabular}{|l|l|l|}
\hline Problems/difficulties & $\begin{array}{l}\text { Frequency } \\
(\mathbf{n}=\mathbf{2 0 9})\end{array}$ & Percentage \\
\hline Lack of one-to-one interaction with students & 192 & 91.9 \\
\hline Poor response from students & 126 & 60.3 \\
\hline Technology failures/internet connectivity issues & 114 & 54.5 \\
\hline $\begin{array}{l}\text { Lack of training regarding the use of digital platforms/ } \\
\text { unprepared for e-teaching }\end{array}$ & 62 & 29.7 \\
\hline Difficulty in creating lesson plans. & 53 & 25.4 \\
\hline Lack of adequate devices/hardware. & 44 & 21.1 \\
\hline Visual fatigue & 40 & 19.1 \\
\hline Increased workload & 37 & 17.7 \\
\hline Personal anxiety/fear of e-teaching & 20 & 9.6 \\
\hline Distractions during teaching & 6 & 2.9 \\
\hline None & 9 & 4.3 \\
\hline
\end{tabular}


Table 5. Benefits of e-teaching. (Multiple responses were allowed)

\begin{tabular}{|l|l|l|}
\hline Benefits & $\begin{array}{l}\text { Frequency } \\
(\mathbf{n}=\mathbf{2 0 9})\end{array}$ & Percentage \\
\hline More content can be shared with students & 122 & 58.4 \\
\hline Increased flexibility of location & 112 & 53.6 \\
\hline Useful during the lockdown period & 102 & 48.8 \\
\hline Beneficial in Development of digital literacy skills & 87 & 41.6 \\
\hline Increased flexibility of time & 62 & 29.7 \\
\hline None & 12 & 5.7 \\
\hline
\end{tabular}

Table 6. Association between difficulty in creating lesson plans and previous expertise in the use of digital platforms like Microsoft Office, email, web search engines, etc

\begin{tabular}{|l|l|l|l|}
\hline \multirow{2}{*}{$\begin{array}{l}\text { Previous expertise in the use of } \\
\text { digital platforms like Microsoft } \\
\begin{array}{l}\text { Office, email, web search engines, } \\
\text { etc. }\end{array}\end{array}$} & \multicolumn{2}{|l|}{ Difficulty in creating lesson plans } & \multirow{2}{*}{ Total } \\
\cline { 2 - 4 } No/Somewhat & No & Yes & 120 \\
\hline Yes & 73 & 37 & 89 \\
\hline Total & 156 & 16 & 209 \\
\hline Pearson Chi-Square: 4.462 & P Value $=.035(<0.05)$ & 53 & \\
\hline
\end{tabular}

Table 5 compiles the benefits of e-teaching. Most teachers felt the major benefit was the vast variety of content available online that can be shared with students (58.4\%), followed by increased flexibility of location (53.6\%), being able to keep in touch with students and the subject even during the lockdown (48.8\%), development of digital expertise (41.6\%), the flexibility of time (29.7\%) and none in $5.7 \%$ cases.

We also recorded responses of teachers on suggestions to improve the current ongoing e-teaching. The majority of the teachers were of the view that e-teaching can be improved only when better platforms in the forms of apps and fast internet facilities are available. Other suggestions were the development of robust curricular systems and IT infrastructure by the institution to incorporate e-teaching and assessment, ensuring access to good internet and hardware for the students at subsidized prices, proper planning of the lesson framework, ensuring better infrastructure and adequate training of the faculty and students regarding how to use digital platforms for this purpose. 
Table 7. Association between technological failures/Internet Connectivity Issues and type of internet connection used for-teaching

\begin{tabular}{|l|l|l|l|}
\hline \multirow{2}{*}{$\begin{array}{l}\text { Internet connection used for } \\
\text { e-teaching }\end{array}$} & \multicolumn{2}{|l|}{$\begin{array}{l}\text { Technological failures/Internet Connectivity } \\
\text { Issues }\end{array}$} & \multirow{2}{*}{ Total } \\
\cline { 2 - 4 } & No & Yes & \\
\hline Institute's internet connection & 64 & 58 & 122 \\
\hline Personal internet connection & 31 & 56 & 87 \\
\hline Total & 95 & 114 & 209 \\
\hline Pearson Chi-Square: 5.800 & $\mathrm{P}=.016(<0.05)$ & & \\
\hline
\end{tabular}

Table 6 states the association between the previous expertise in the use of digital platforms and difficulty in creating lesson plans. It states that teachers with expertise in the digital field faced less difficulty in creating lesson plans as compare to the teachers with no or little expertise. $\mathrm{P}$-value was statistically significant in this case. $(\mathrm{P}=.035)$

Table 7 shows the association between the type of internet connection used for e-teaching and technological failures or Internet Connectivity Issues. It states that the faculty members who were using the institute's internet were facing less technological issues as compared to the faculty members using their personal internet. P-value was less than $0.05(\mathrm{P}=.016)$

\section{Discussion}

The present study identifies the perception of medical faculty regarding online teaching methodology. The study emphasizes barriers in the conduction of online classes, motivators for online teaching, training organized to familiarize the faculty to digital platforms, and incorporation of online teaching in the medical curriculum.

This study reports several barriers perceived by the faculty of medical and associated colleges, which present a challenge in continuing medical education. These problems can be divided into external and internal factors. External factors are institutional-based factors and internal factors relate to the users themselves. External factors in this study were frequent technology failures/ poor internet connection, lack of training regarding the use of digital platforms, lack of adequate devices/ hardware, and Increased workload. Internal factors were lack of personal interaction with students, poor response from students, difficulty in creating lesson plans, visual fatigue, and personal anxiety/fear of e-teaching, and distractions during teaching.

Al-Azawei et al., reported similar findings in their study. External challenges reported by them were low internet bandwidth, insufficient financial support, inadequate training programs, lack of technical support, lack of adequate devices/infrastructure, and frequent electricity shortage. Internal factors identified by their study were lack of awareness, interest, motivation, and e-learning literacy ${ }^{4}$. The barriers to e-learning reported by Kwofie B were inadequate organizational capacities to accommodate online learning and the use of educational technologies; rigidly designed curricula and instructional delivery methods; lack of ICT and general infrastructural support systems including network security, high-speed internet, users' competencies and integrated institutional policies; fear of reform or change; fear of losing the human touch and the issue of digital content design and development $\underline{\underline{5}}$.

Similarly, other studies report barriers such as lack of computer and typing skills $s^{6}$, the inadequate time to learn e-teaching tools and to prepare lesson plans ${ }^{7}$, lack 
of infrastructure and technology $\frac{8-10}{}$, lack of institutional support and direction ${ }^{11}$, and negative attitude amongst educators in engaging with new technologies ${ }^{6,12,13}$.

In the present study, most teachers hadn't received any kind of training on the use of digital platforms for e-teaching which adds to the list of barriers to e-teaching. Contrastingly A study by Dery $S$ et al., stated that almost all the respondents had undertaken some form of training with most indicating self-guided learning as their mode of learning about digital platforms. Few respondents reported having undertaken a computer science or IT related course. Pharmacy and Medical schools had the highest proportions that have ever undertaken some computer science or IT related courses $\frac{14}{}$. A study by Maguire et al mentions lack of training as one of the deterrents to teaching online $\mathrm{e}^{\frac{15}{5}}$. Rensburg reports that limited computer training of educators and the lack of information technology support to solve technical problems are challenges for online teaching ${ }^{16}$. Kowalczyk NK reports that insufficient information technology training and competence were indicated by educators (faculty) as a barrier in online teaching ${ }^{17}$.

The benefits of e-teaching as perceived by the teachers in the present study were the ability to share more content with the students online, increased flexibility of time and location, opportunity to keep in touch with the subject during lockdown and development of digital literacy. The benefits of e-teaching enlisted by Gupta S were suitability to ones' needs, access to updated content, quick delivery of lessons, scalability, consistency, reduced cost and more effectiveness and less impact on the environment ${ }^{\frac{18}{}}$. Some e-teaching benefits reported by Stoeva $\mathrm{Z}$ were staying connected with students, the flexibility of resources, innovation, 24-hour accessibility to content, better communication with parents, time saver, greener and cost-effective, more creativity in lesson plans, lifelong learning for teachers, opportunities for self-reflection and feedback ${ }^{19}$. The benefits of e-teaching as reported by other studies include Flexibility of location and time $e^{15,20}$, easy accessibility of online materials anytime ${ }^{21}$, enhancing computer literacy skills $s^{\underline{14}}$, feeling of self-gratification and job satisfaction $\frac{22}{}$, improvement in confidence and ability to keep up to date ${ }^{23}$.

In the present study, almost half (49.8\%) of the participants were of the view that e-teaching can be included as the routine teaching modality along with classroom teaching. The combination of traditional classroom teaching and e-teaching (e-learning) is referred to in the literature as blended learning. Button et al report in their study that educators are more in favor of blended teaching and learning ${ }^{24}$. Regmi and Jones also report that better learning can be obtained by using the blended teaching modality 21 .

Hence it can be concluded from this study that online teaching cannot be a substitute to routine classroom teaching, however, it can be used as a supplement along with routine teaching to share more content with the students, to give assignments, to receive feedback, etc. as suggested by most of the participants in this study. As e-teaching is the need of the hour and we have to continue with this teaching modality till everything normalizes, what can be done for the time being is include more interactive methods and content in the online lectures, build the necessary infrastructure for this purpose, like strong internet connectivity, hardware and devices required for the classes, arrange effective training for the teachers on the use of digital platforms, reduce the burden of teachers by providing technical assistance in designing of the lesson plans.

\section{References}

1. Teaching during Covid-19 lockdown: Coping up with online classes and excelling. India Today. Available from: https://www.indiatoday.in/ education-today/featurephilia/story/teaching-duringcovid-19-lockdown-coping-up-with-online-classesand-excelling-1675013-2020-05-06.

2. Servage L. Strategizing for workplace e-learning: Some critical considerations. Journal of Workplace Learning. 2005 Jul; 17(5/6):304-17. Available from: https://www.emerald.com/insight/content/ doi/10.1108/13665620510606733/full/html. https:/doi. org/10.1108/13665620510606733.

3. Awasthi P. Online classes turning out to be nightmare for teachers amid COVID-19 lockdown. The Week. 2020 May 23. Available from: https://www.theweek.in/ news/india/2020/05/23/online-classes-turning-out-tobe-nightmare-for-teachers-amid-covid-19-lockdown. html

4. Al-Azawei A, Parslow P, Lundqvist K. Barriers and opportunities of e-learning implementation in Iraq: A case of public universities. The International Review of 
Research in Open and Distributed Learning. 2016 Sep 26; 17(5). Available from: http://www.irrodl.org/index. php/irrodl/article/view/2501. https://doi.org/10.19173/ irrodl.v17i5.2501.

5. Kwofie B. Barriers to online learning adoption in higher education [Internet]. University World News. 2020. Available from: https://www.universityworldnews.com/ post.php?story=20200506200743715.

6. Niebuhr V, Niebuhr B, Trumble J, Urbani MJ. Online faculty development for creating e-learning materials. Education for health. 2014 Sep 1; 27(3):255. Available from: http://www.educationforhealth.net/article. asp ?issn $=1357-6283$; year $=2014$; volume $=27$;issue $=3$; spa ge $=255$; epage $=261$; aulast $=$ Niebuhr;type $=0$. https:/doi. org/10.4103/1357-6283.152186. PMid:25758389.

7. Wilson FC. Teaching by residents. Clin Orthop Relat Res. 2007 Jan; 454:247-50. https://doi.org/10.1097/ BLO.0b013e31802b4944. PMid:17091017.

8. Bediang G, Stoll B, Geissbuhler A, Klohn AM, Stuckelberger A, Nko'o S, et al. Computer literacy and e-learning perception in Cameroon: the case of Yaounde Faculty of Medicine and Biomedical Sciences. BMC Med Educ. 2013 Apr 19; 13:57. https://doi.org/10.1186/14726920-13-57. PMid:23601853 PMCid:PMC3637556.

9. Attardi SM, Rogers KA. Design and implementation of an online systemic human anatomy course with laboratory. Anat Sci Educ. 2015 Feb; 8(1):53-62. https:// doi.org/10.1002/ase.1465. PMid:24920278.

10. Lakbala P. Barriers in implementing e-learning in Hormozgan University of Medical Sciences. Glob J Health Sci. 2016 Jul; 8(7):83-92. Available from: https:// www.ncbi.nlm.nih.gov/pmc/articles/PMC4965673/. https://doi.org/10.5539/gjhs.v8n7p83. PMid:26925885 PMCid:PMC4965673.

11. Bury R, Martin L, Roberts S. Achieving change through mutual development: supported online learning and the evolving roles of health and information professionals. Health Info Libr J. 2006 Dec; 23 Suppl 1:22-31. https://doi. org/10.1111/j.1471-1842.2006.00677.x. PMid:17206993.

12. Skye EP, Wimsatt LA, Master-Hunter TA, Locke AB. Developing online learning modules in a family medicine residency. Fam Med. 2011 Mar; 43(3):185-92.

13. NHMRC additional levels of evidence and grades for recommendations for developers of guidelines. National Health and Medical Research Council (NHMRC): Canberra. Available from: https://www.mja.com.au/
sites/default/files/NHMRC.levels.of.evidence.2008-09. pdf.

14. Dery S, Vroom F da-Costa, Godi A, Afagbedzi S, Dwomoh D. Knowledge and use of information and communication technology by health sciences students of the University of Ghana. Ghana Med J. 2016 Sep; 50(3):180-8. Available from: https://www.ncbi.nlm.nih. gov/pmc/articles/PMC5044793/.

15. Maguire LL. Literature review-faculty participation in online distance education: Barriers and motivators. Online Journal of Distance Learning Administration. 2005; 8(1):1-16.

16. Janse van Rensburg ES. Effective online teaching and learning practices for undergraduate health sciences students: An integrative review. International Journal of Africa Nursing Sciences. 2018 Jan 1; 9:73-80. Available from: http://www.sciencedirect.com/science/article/ pii/S2214139118300398. https://doi.org/10.1016/j. ijans.2018.08.004.

17. Kowalczyk NK. Perceived Barriers to Online Education by Radiologic Science Educators. Radiol Technol. 2014 May 1; 85(5):486-93. Available from: http://www. radiologictechnology.org/content/85/5/486.

18. Gupta S. 9 benefits of elearning for students. eLearning Industry. 2017 Available from: https://elearningindustry. com/9-benefits-of-elearning-for-students.

19. Stoeva Z. What Are the Benefits of E-Learning for Teachers. VEDAMO. 2018. Available from: https://www. vedamo.com/knowledge/benefits-of-e-learning-forteachers/.

20. Ortega J, Cometto MC, Zárate Grajales RA, Malvárez S, Cassiani S, Falconi C, et al. Distance learning and patient safety: Report and evaluation of an online patient safety course. Revista Panamericana de Salud Pública. 2020 May 20; 44:1. https://doi.org/10.26633/RPSP.2020.33. PMid:32435264 PMCid:PMC7236860.

21. Regmi K, Jones L. A systematic review of the factorsenablers and barriers- affecting e-learning in health sciences education. BMC Medical Education. 2020 Mar 30; 20(1):91. Available from: https://doi. org/10.1186/s12909-020-02007-6. PMid:32228560 PMCid:PMC7106784.

22. Rockwell SK, Schauer J, Fritz S, Marx DB. Incentives and obstacles influencing higher education faculty and administrators to teach via distance. Faculty Publications: Agricultural Leadership, Education and Communication Department; 1999. p. 53. 
23. Barber JRG, Park SE, Jensen K, Marshall H, McDonald P, McKinley RK, et al. Facilitators and barriers to teaching undergraduate medical students in general practice. Medical Education. 2019; 53(8):778-87. Available from: https://onlinelibrary.wiley.com/doi/abs/10.1111/ medu.13882. https://doi.org/10.1111/medu.13882. PMid:31012131.

24. Button D, Harrington A, Belan I. E-learning and Information Communication Technology (ICT) in nursing education: A review of the literature. Nurse Education Today. 2014 Oct 1; 34(10):1311-23. Available from: http://www.sciencedirect.com/science/article/ pii/S0260691713001652. https://doi.org/10.1016/j. nedt.2013.05.002. PMid:23786869. 